\title{
Tourism Waste Management in the European Union: Lessons Learned from Four Popular EU Tourist Destinations
}

\author{
Chukwunonye Ezeah'1, Jak Fazakerley², Timothy Byrne ${ }^{3}$ \\ ${ }^{1}$ Faculty of Sciences and Engineering, University of Wolverhampton, City Campus-South, Wolverhampton, UK \\ ${ }^{2}$ Royal Haskoning DHV UK Ltd., Honey Comb, Liverpool, UK \\ ${ }^{3}$ School of Sciences and Technology, The University of Northampton, Northampton, UK \\ Email: C.Ezeah2@wlv.ac.uk
}

Received 14 August 2015; accepted 13 December 2015; published 16 December 2015

Copyright (C) 2015 by authors and Scientific Research Publishing Inc.

This work is licensed under the Creative Commons Attribution International License (CC BY).

http://creativecommons.org/licenses/by/4.0/

(c) (i) Open Access

\section{Abstract}

From a sustainability perspective, achieving greater efficiencies in environmental waste management is at the heart of current academic discussion on climate change science. Over the last few decades the tourism industry has developed exponentially and is now considered one of the most dynamic economic activities worldwide. Solid waste is a commonly identified and ever increasing aspect of tourism; the improper management of which can lead to substantial and irreversible direct and indirect environmental, economic and social impacts. However, the management of solid waste in tourism dominated island communities is particularly problematic due to climatic conditions, topography, financial restraints, planning issues, changing consumption patterns, transient population, and seasonal variations in solid waste quantity and composition. In addition, there is often a lack of momentum to implement new initiatives and programs as stakeholders involved in the design, construction and operation of tourist resorts have conflicts of interest. Using information gathered from key informant interviews, participation observations and literature reviews, this article appraises current waste management practices in four European tourist destinations, namely: Mallorca, Tenerife, Kefalonia and Rhodes. Findings indicate that, although there are signs of compliance with global best practice, a variety of locally-based measures need to be implemented to enhance sustainability.

\section{Keywords}

Waste Management, Tourist Destination, Island Communities, European Union, Greenhouse Gas Emission 


\section{Introduction}

From a sustainability perspective, the improvement of waste management practices of the European Union (EU) hospitality industry has become very necessary. This is partly because of reported empirical evidence linking improper waste management with greenhouse gas (GHG) emissions. In this regard, management of solid waste in tourism dominated small island communities presents particular challenges due to their peculiar climatic conditions, topography, transient population, and seasonal variations in the quantity and composition of waste materials. A critical ingredient towards achieving this objective is Directive 2008/98/EC of the European Parliament 2008, also known as the Waste Framework Directive (WFD). Based on the requirements of the WFD, all EU member states must have systems in place for sustainable management of municipal solid waste (MSW), which should incorporate the following 1 ) waste minimization 2) reuse 3) recycling 4) energy recovery 5) landfill deposal. It must be said however, that how much waste is actually generated varies significantly between countries within the EU; richer countries tend to produce more waste per person. For instance, municipal waste generated per person varies from $294 \mathrm{~kg}$ in the Czech Republic to $801 \mathrm{~kg}$ in Denmark [1]. Out of all the municipal waste generated in the EU, $42 \%$ is landfilled, $38 \%$ is recovered and $20 \%$ is incinerated. Poorer countries tend to rely mostly on landfills for waste disposal while richer countries are the biggest users of incineration. The highest amount of waste is landfilled in Bulgaria, Romania, Lithuania, Malta and Poland (90\% or more); Germany, Belgium, the Netherlands and Austria recycle or compost the most (59\% or more); while Denmark, Luxembourg, and Sweden incinerate the largest proportion (47\% or more). From a pan European position, though landfills are generally regarded as the least desirable of options for waste disposal, closing landfills may not be feasible until all member states and regions have developed capacities for alternative disposal options. This is especially so for new member states and regions with challenging socio-economic and environmental conditions. Touristic Islands exemplify EU regions with characteristic limitations which often affect how waste is collected, transported, treated and disposed. Such locations have common waste management problems which may include:

- Reduced number of facilities for waste treatment or disposal.

- Significant variations in waste arising based on tourism season.

- High population density.

- Limited land mass to locate landfills and other waste treatment infrastructure.

- Difficulties in achieving economies of scale [2].

Over the last few decades EU tourism industry has developed considerably and is now considered one of the most dynamic globally. Despite the phenomenal growth recorded by the sector, research has lagged behind with respect to waste arising from its operations; this situation is compounded by the near absence of reliable data on waste management in the sector.

Notwithstanding, solid waste remains an important aspect of tourism both with the EU and globally. It has been estimated that the industry produces around 35 million tonnes of solid waste annually [3]-[5]. Mateu-Sbert et al. [6] estimated that on the average, $1.41 \mathrm{~kg} /$ day of solid waste was generated per resident in EU-27 countries during 1998-2010. Solid waste management (SWM) is therefore a critical, complex and multi-dimensional challenge facing the EU hospitality sector in particular and the world in general [7] [8]. It is therefore important that the tourism industry continues to improve and adapt its operation towards waste minimization; following that, waste should be collected, transported and disposed of in an environmentally sound and cost-effective manner, so as to help achieve overall EU climate change objectives [6]. Improper management of waste can lead to substantial and irreversible environmental, economic and social impacts, such as increases in greenhouse gas emission, land degradation, resource deprivation, surface and groundwater water pollution, loss of biodiversity and the loss of aesthetic value of tourism locations [9] [10].

The management of solid waste in tourism dominated island communities is particularly problematic due to climatic conditions, land mass and topography, financial restraints, poor planning, changing consumption patterns, transient population (i.e. tourism flows), and seasonal variations in solid waste quantity and composition [3]. The isolated geographies of most islands communities also mean that materials are most times imported with little or no thought as to how to manage waste that arise after those materials might have been used. This situation often exacerbates the pressure on carrying capacity of the islands waste management infrastructure and further challenges the inefficient and unsustainable management practices of waste collection and disposal [10].

In addition, there is also sometimes a noticeable lack of momentum to implement new initiatives and programs designed to ameliorate the situation. Many stakeholders are involved in the design, construction and operation of tourist resorts, including municipal managers and planners, project developers and constructors, real 
estate brokers, hotel managers, tour operators and local residents [10]; all of whom operate in a highly complex environment and have different priorities [11]. For example, the tourists themselves do not feel responsible for the waste problem as they stay for only short periods of time and do not develop social ties with places they visit [6]. Furthermore, as Von Bertrab et al. [11] argue, waste management is still largely perceived as an additional cost instead of as an income generating resource. Evidently, giving the above situation, finding ways to involve all stakeholders and promoting sustainable solid waste management (SSWM) in most tourism establishments has continued to remain a challenging and complex issue.

As a solution, it has been suggested that public-private partnerships (PPP) could play a key role in this direction. Using information gained from key informant interviews, participant observations and literature reviews, this article attempts an appraisal of waste management practices of four Mediterranean tourism destinations: Mallorca, Tenerife, Kefalonia and Rhodes, focusing particularly on collection, transportation, disposal as well as stakeholder collaboration. The paper concludes with a number of key recommendations that could be utilised to inform future decisions on sustainable waste management in the regions. Whilst island regions are not usually subject to the same level of legislative control as larger mainland states (for example, with regard to key EU Directives on waste management), it is usual for Island local authorities to seek to adopt strategies and to introduce facilities and technologies that at least go some way towards reflecting the high standards set out in European or other similar legislation. Within EU legislation, including that relating to waste based on the principles of the EU Waste Framework Directive and Landfill Directive. Having said this, the challenge of seeking to apply these strict standards to small islands must be recognized and in such cases exemptions or derogations could apply.

\subsection{Engaging the Public-Private Partnership Model for Sustainable Waste Management in Small Islands}

Public-private partnerships (PPP) have been identified as effective tools for improving service provision in the waste management sector [10]. This is more so because, collaborative approaches to governance and decision making help to address problems too complex to be effectively resolved by independent action [7]. Willmott and Graci [3] argue that traditional top-down, regulatory and end of pipe approaches to waste management often leads to a variety of challenges particularly in Island communities, including technical concerns, financial restraints, a lack of capacity, limited education and awareness, corruption, stakeholder influence and poor planning. However, an inclusive working relationship between, for example, government agencies, local authorities, technical consultants, hotels, waste companies, social enterprises, banks, residents and tourists can allow for access to resources, networks, financial support, training, technical assistance, knowledge exchange and experience [11]. These facets can then best be utilised to identify problems, set direction and implement initiatives to improve solid waste management under a common strategy [7]. McDevitt [12] believes that when a system is reflective of stakeholder concerns, individuals and organisations are more likely to provide support. Engaged and facilitated dialogue can therefore lead to a better regulatory and institutional framework, based upon complementarity, subsidiarity and neutrality, which can ultimately improve transparency and accountability within the waste sector [10]. However, for a high-quality waste and resource management service to develop and expand, PPPs need to remain dynamic; incorporating a number of environmental, economic, social and technical criteria which are underpinned by relevant legislation [6].

In the case of Small island locations for instance, key stakeholders such as tour operators could play a vital role in facilitating Public-private partnerships engagement for efficient delivery of waste management services. It has been noted however that in some instances, external factors may affect the sustainability of services [13]. For example, a destination's wastewater treatment system, waste management scheme, policies on the protection of cultural and natural heritage or social conditions may all influence the sustainability of performance. Where such external factors limit improvements in sustainability performance, it may be necessary to work in partnership with local and national government authorities [14]. It is important to recognize that the circumstances and priorities of some destinations may be very different, so it is necessary to avoid approaches that would impose undue burdens on local authorities [15].

\subsection{Models for Sustainable Waste Management in the Tourism Sector}

1) Sustainable waste management in the tourism sector of the Mexican Caribbean

In October 2008, GIZ, the Swiss travel agent Kuoni Travel Holding, the non-governmental organisation 
Amigos de Sian Ka'an (with financing from Travel Foundation Netherlands) and the State of Quintana Roo's Ministries for the Environment and Tourism agreed on measures to promote integrated waste management in the region as part of a development partnership with the private sector [16].

Specifically, the project partners made the following contributions:

- GIZ: Advisory services on formulating pilot plans for integrated waste management in hotels, project management, workshop moderation, appointing consultants to provide a market analysis of local waste collection and the recycling industry;

- Kuoni Travel Holding: Financing workshops to raise awareness among the tourism industry;

- Amigos de Sian Ka'an (Travel Foundation Netherlands): Financing and conducting campaigns to raise awareness among hoteliers and tourists, coordinating activities on the ground; and

- Quintana Roo Ministry for the Environment and Quintana Roo Ministry for Tourism: Creating the legislative and regulatory conditions to introduce waste management plans in the tourism sector, taking care of experts on the ground.

The project created a legislative framework for standard waste management plans in hotels in the Mexican Caribbean, allowing the plans to be introduced across the board. The project also raised awareness among tourists, hoteliers and their employees with a focus on environmental issues on the ground and providing practical tips on preventing waste [16].

2) Bay of Bengal Green Model for Eco-Tourism

The Welcomegroup Bay Island (WGBI) hotel, owned and operated by ITC-Welcomegroup, is located in Port Blair, the capital city of the Andaman and Nicobar Islands, an archipelago in the Bay of Bengal. As a result of its geographic location, the islands rely mostly almost completely on the Indian mainland for all food supplies, medicines and items of daily use. Initially there was a lack of systems, procedures and policies surrounding waste management incentives and disincentives at the hotel. As such, the hotel created a green strategy, based on the Four-R principle, to produce an eco-tourism model for the island. The hotel addressed the issues by adopting both internal and external strategies [17].

Internal Strategy - Initially, tourists went for sightseeing trips to other islands in Port Blair with lunches packed in cardboard boxes. These boxes were invariably left behind on the islands thereby creating a waste problem. The hotel replaced cardboard boxes with steel lunch boxes. Users had to return the boxes or pay a fine. Through discussion and policy change, the system eliminated the recurring cost of buying cardboard boxes and reduced the garbage levels on the other islands.

External Strategy - The Andaman \& Nicobar Tourism Guild (ANTG) convinced the local government to position the island for high-end tourism in order to seed the local economy and reduce the pressure on the already scarce resources by restricting the number of tourist through cost measures. The chain has since become the first eco-responsible chain in India. Initial costs of the hotel's activities were shared with its competitors, the local administration and hotel guests, leading to a cascading effect in terms of echoing eco-tourism practices. In recognition for their work they received The British Airways Tourism Award for Environment, subsequently leading to image and operational advantages [17].

\section{Methodology}

Figure 1 is an outline of the multi-stage methodological approach adopted for this investigation, covering desktop study, fieldwork and data analysis/prescription stages. The preliminary stage of the investigation involved the identification and review of relevant literature on tourism waste management in the European Union [18] [19] as well as a key informant interview with 8 stakeholders in waste management such as tourists, residents, hotel managers, local authority staff etc. Following this, four key EU tourist destinations, Mallorca, Tenerife, Kefalonia and Kalithea-Rhodes were selected as case studies using the purposive sampling technique. Apart from being geographically representative, the four Islands together account for a significant percentage of EU bound tourism and as such provide ideal case studies for this investigation. Adopting participant observation methodology, primary data on waste management were collected from the four case study locations between 2008 and 2012. A focus group discussion comprising 10 experts drawn mostly from the tourism and hospitality sector in Kalithea-Rhodes was also held to aggregate and validate some of the findings from the study. Data collected were mostly qualitative in nature; analysis of quantitative data was carried out using Microsoft Excel for Windows. 


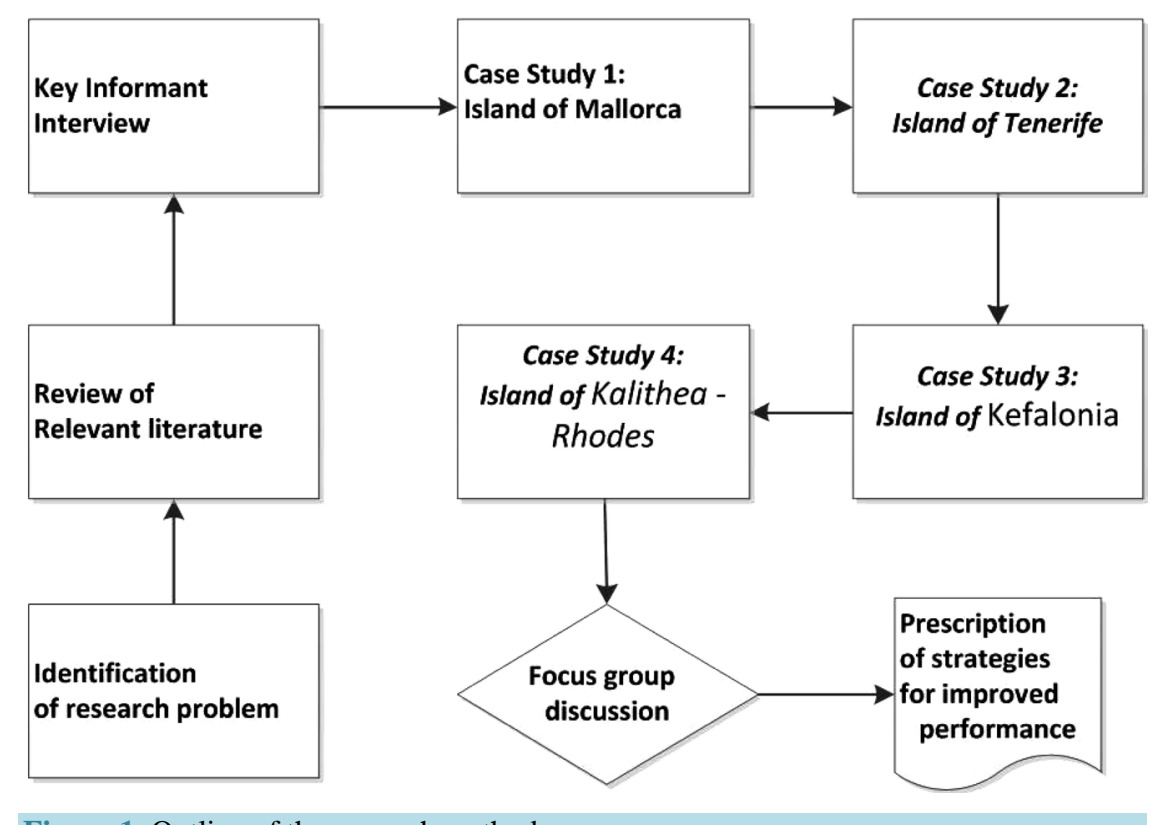

Figure 1. Outline of the research method.

\subsection{Case Study 1: Tourism Waste Management on the Island of Mallorca}

Mallorca is a Spanish island located in the Mediterranean Sea. It is the largest island in the Balearic Islands archipelago (Figure 2). It has a population of approximately 870,000 (2010 census) and covers a total land area of $3640 \mathrm{~km}^{2}$. The climate is largely Mediterranean, with mild to cool winters and hot, bright summers [6]. This facet, along with picturesque beaches, rugged coastlines and high-quality amenities, makes the island a popular tourist destination-with over 6 million holiday makers visiting the island in 2010 [20]. It is estimated that as much as half of the population now work in the tourist sector, which accounts for approximately $80 \%$ of Majorca's GDP. In 2014, three additional beaches in Mallorca, Sant Elm, Camp de Mar and the Sailing Club in Port Andratx gained Blue Flag status, a recognition of the very high water quality, environmental management, safety and services [21].

The Island of Mallorca has a modern, integrated waste management system. In 1992, the Government of Mallorca signed a major contract for the operation and management of five waste transfer stations for the local municipalities. Municipal and commercial waste is delivered to the Son Reus energy from waste plant near Palma [21]. In 2010, the energy from waste plant was expanded with the commissioning of two grate-fired thermal treatment lines each having a throughput of 30 tonnes per hour. A new tipping hall was also constructed for the additional two lines and the plant expansion can now deal with municipal and commercial waste, biomass, sewage sludge and small quantities of waste tyres [22]. The overall throughput of the energy from waste facility is now 800,000 tonnes per annum and since the plants expansion, has ended the use of landfill for municipal and commercial waste disposal on the island of Mallorca [23].

As with most areas in Spain, waste collection on the Island is at night with collection vehicles starting their route around 2300 hours. However, the energy from waste facility and transfer stations are operational on a 24 hour basis [22]. As part of a separate contract, the transportation of waste materials from the five transfer stations around Mallorca to the energy from waste facility in Son Reus was signed with ALCUDIA SA [23]. This company utilises a semi-trailer fitted with Marrel hook loader equipment which is then pulled by a tractor unit fitted with the necessary hydraulics to operate the hook loader system fitted to the semitrailer. It was observed that staffs who work at these transfer stations comply with all European health and safety guidelines [23].

However, Zero Waste Europe [24] believe that Mallorca can be seen as "the best and the worst" of waste management in southern Europe. On one hand some, zero waste municipalities have implemented ambitious door-to-door source separation schemes which would allow them to recycle more than $75 \%$ of the waste (i.e. Esporles and Puigpunyent). On the other hand, the island currently only produces around 540,000 tonnes of waste per annum meaning that vast quantities are imported from many $\mathrm{km}$ away to keep up with the operational capacity of the incinerator. This contradicts the proximity principle, the waste hierarchy and European Resource 


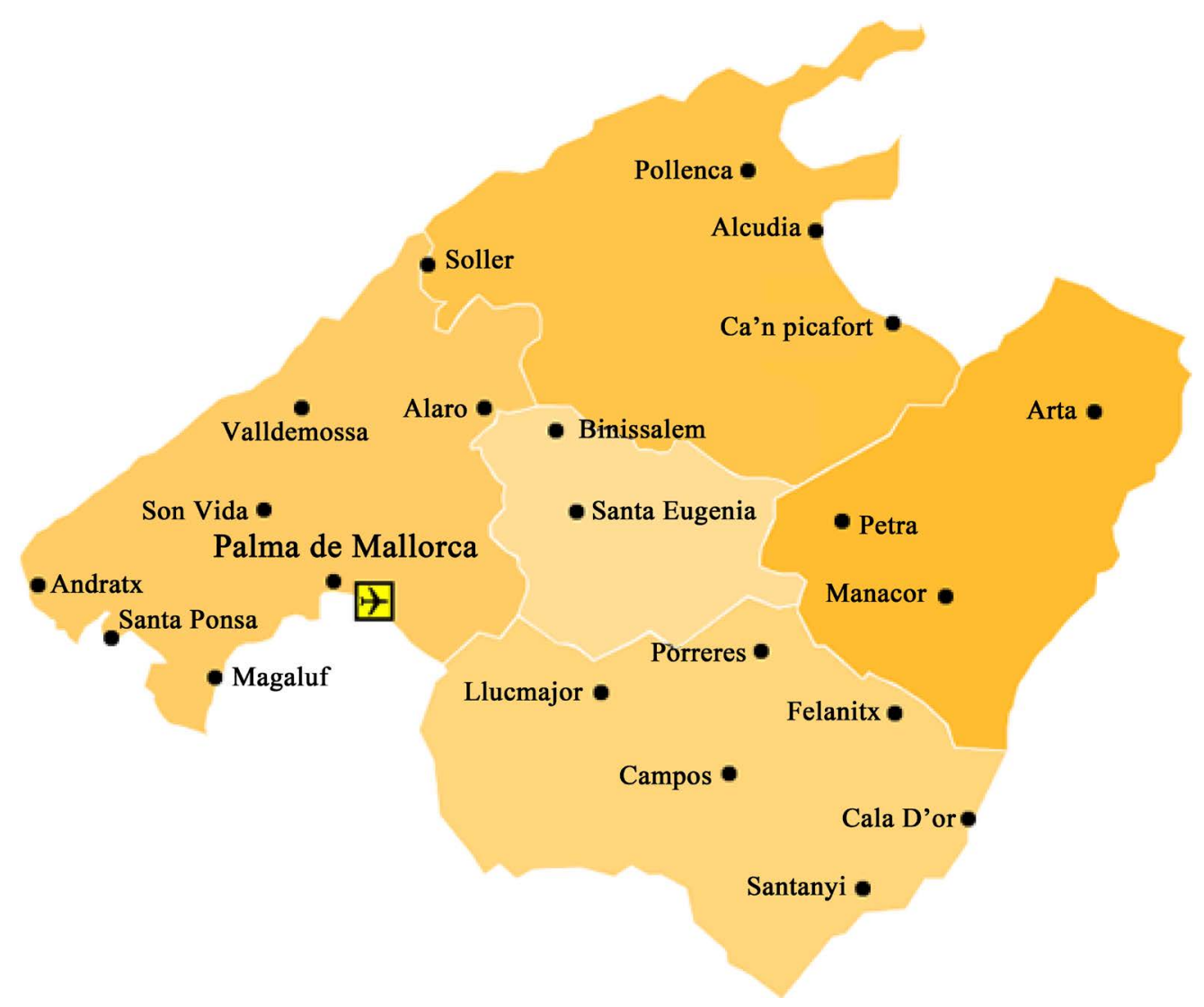

Figure 2. Map of the Island of Mallorca, Spain.

Efficiency Roadmap. As such, it is unlikely that the targets set by the EU will be accomplished unless the economic and legislative drivers are changed to prioritise recycling.

\subsection{Case Study 2: Tourism Waste Management on the Island of Tenerife}

Tenerife, the largest of the Canary Islands, is one of Europe's most popular tourist destinations. The island's warm climate attracts five million holidaymakers every year, so managing the collection and treatment of municipal solid waste is a very important task [25]. On the south west coast of the island is the district of Santiago Del Teide, located close to the island's active volcano Mount Teide, the third largest in the world. The district is made up of several towns, villages and coastal resorts, i.e. El Molledo, El Retamar, Tamaimo, Los Gigantes (which also has the highest volcanic cliffs in Europe), Puerto de Santiago, and Playa de la Arena (Figure 3) [26].

1) Waste Collection

Waste is collected on a district basis, mostly by small family owned businesses [21]. Waste is collected in 660 litre containers, since there is limited space to place 1100 litre containers in the district (Figure 4). The containers are located in communal collection points along the street, where up to six containers could be placed. Although these containers are smaller than the 1100 litre option, the number of 660 litre containers stored in each communal point has adequate capacity for the waste produced [27]. Tourists, residents, retail outlets and bars place their residual waste into nearby communal containers. Usually, there is also an igloo in each compound for glass, bottles, paper and card recycling. The recyclables are collected by a third party on behalf of the Island's council. There is also an underground waste collection system in operation in the three coastal resorts. Waste is placed into loading apertures at street level, and then falls into a roll on/off container stored below street level. This helps to improve the area's appearance and keep odour and vermin to a minimum in the warm weather [26].

In Santiago Del Teide waste is collected at night from 22.00 hours until 05.00 hours. The collection service is operated seven days a week, throughout the year [25]. Waste collection vehicles are manned in the spring season 


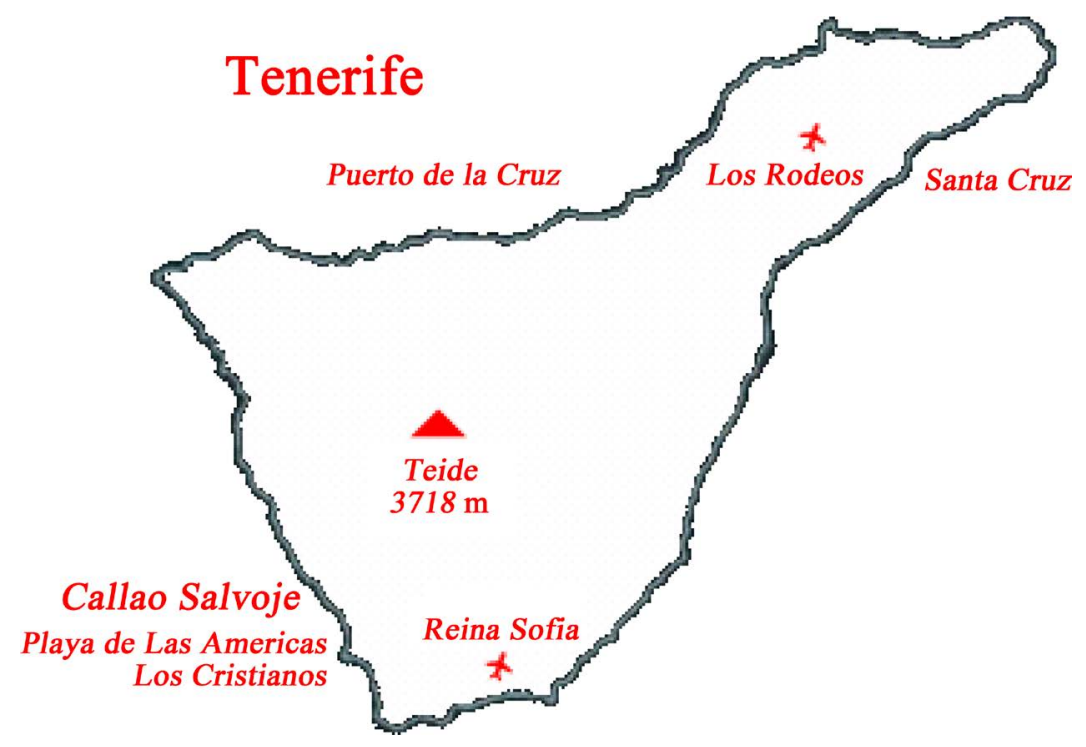

Figure 3. Map of Tenerife, the Canary Islands.

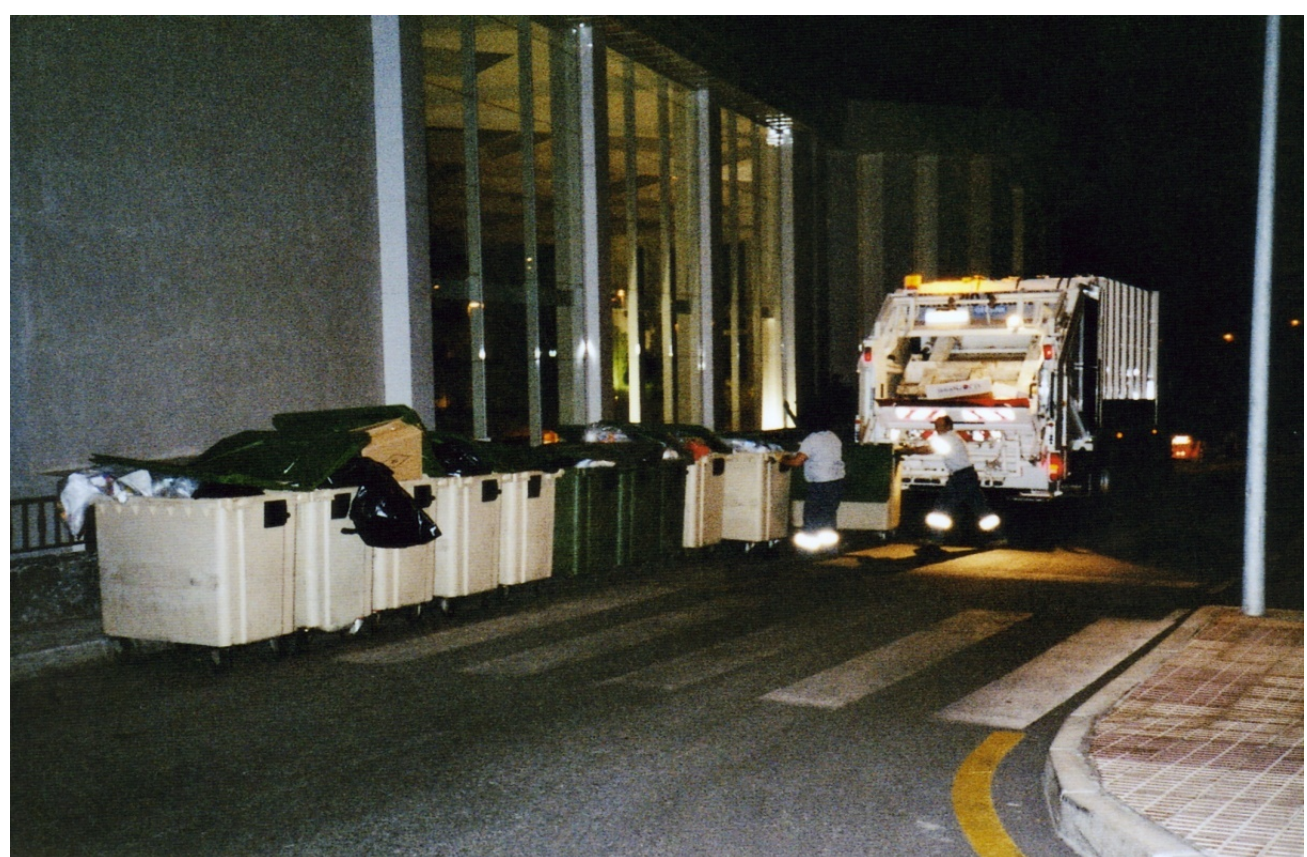

Figure 4. A private contractor emptying 660 litre waste containers in a hotel in playa de la arenaTenerife (authors photograph).

by a driver and one loader, the driver helping the loader place the containers at the rear of the refuse collection vehicle to be emptied. In the summer season, when tourist numbers increase, each vehicle is manned with a driver and two loaders, to handle the extra waste produced in the district.

There is also a roll on/off vehicle fitted with Multilift HL5 hook lift mounted on a two axle Iveco Eurocargo chassis which collects the full roll on/off containers from the underground waste collection systems. The vehicle travels to the various underground waste collection systems with an empty roll on/off container so reloading of fresh waste can continue throughout the night.

Each refuse collection vehicle collects one to two loads a night depending on the number of tourists in the resort and the amount of waste being generated [25]. Once all of the vehicles have finished their collection rounds they travel together to the waste transfer station. 
2) Bin and street washing

The 660 litre containers are steam cleaned once they have been emptied. Vehicles carrying out this task have the capacity to transport as much as 7000 litres of water [27]. The water is heated so that when the containers are washed they are disinfected to eradicate any odours or bacteria left from the waste collection process. This service is carried out in all districts of Santiago Del Teide. The bin washer also has the ability to wash the streets after the waste collection service has taken place [21] [26]. Street washing is carried out through the two water jets fitted in the front bumper of the vehicle (Figure 5).

3) Waste Transfer Station Buzanada-El Malpaso-Arona

All waste produced from Santiago Del Teide, and from the neighbouring districts of Guia de Isora, Costa Adeje, Playa de Las Americas-ARONA-Los Cristianos, San Miguel de Abona and Granadilla de Abona is delivered to the waste transfer station at Buzanada-El Malpaso-Arona [27]. The facility is one of four operated on the island by UTE—a company formed by Vertresa and the Cabildo Insular de Tenerife. Vetresa is owned by Urbaser S.A., Spain's second largest waste management contractor [21]. The facilities are located at: BuzanadaEl Malpaso-Arona, La Guancha, La Orotava-Puerto de la Cruz and El Rosario-Santa Cruz de Tenerife [25]. On arrival, all refuse collection vehicles are weighed on the computerised weighbridge [21]. Once weighed, the refuse collection vehicles proceed to one of two static compactor loading apertures [25]. The number of compacting apertures varies at each waste transfer station depending on the throughput of waste. The largest waste transfer station on the island is at El Rosario-Santa Cruz de Tenerife [27]. The collection vehicles reverse up to the unloading aperture and the driver discharges his load into the compactor. The waste is compacted into hermetically sealed roll on/off compaction containers. Once the containers are full they are collected from the compactor by a Marrel roll on/off vehicle. A fresh container is unloaded and fixed to the compactors' loading apertures so that the reloading of waste can continue [28].

4) Dirty MRF and Sanitary landfill site of Arico

The waste from all four waste transfer stations is delivered to the dirty MRF at the site of the sanitary landfill at Arico, located in the south east of the island [27]. The dry recyclables and food waste is extracted and segregated from the remaining municipal waste to help the island meet its EU Landfill Directive (1999/31/EC) targets as well as targets set by the Revised Waste Framework Directve (2008/98/EC). The dry recyclables are sorted through a series of trommels inside the MRF while the organic waste fraction is fermented in composting tunnels. The rejects are land filled under sanitary conditions [21]. The facility incorporates a methane extraction system, with the methane produced from the waste decomposition extracted from the landfill body and harnessed through a turbine [25]. The electricity produced from this process is exported to the national grid. Leachate is treated on site in the leachate lagoons at the desalination plant. Once it has been purified, the leachate is discharged into the ground water sewerage system. The facility also incorporates storage facilities for recyclable materials collected from across the island before they are transported for reprocessing.

\subsection{Case Study 3: Tourism Waste Management on the Island of Kefalonia, Greece}

Kefalonia is the largest of the Ionian Islands. Between the months of May to October, it is home to many

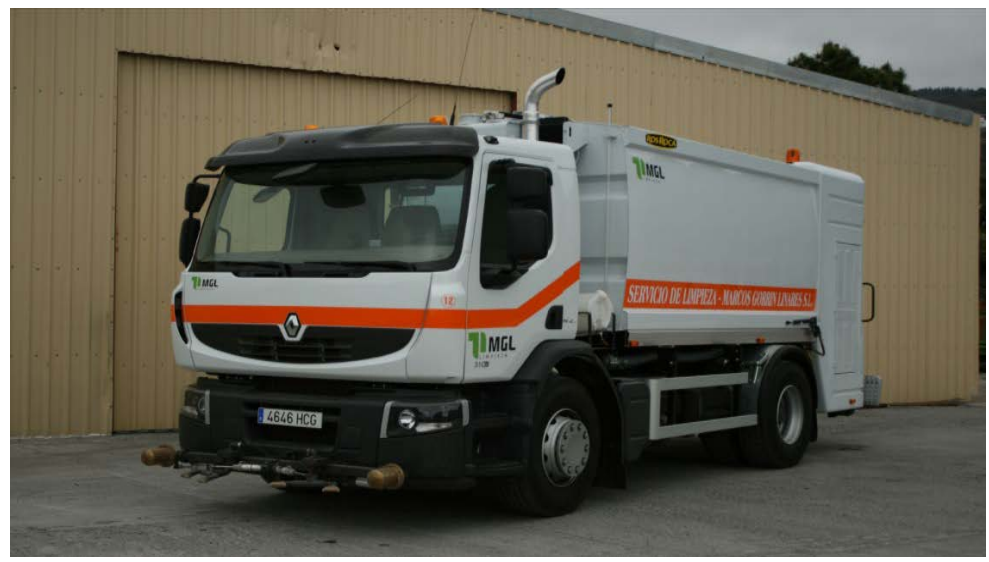

Figure 5. Bin washing in the municipality of Santiago del Teide—Tenerife (authors photograph). 
thousands of tourists. Dealing with waste management on the island is a very important task because of the large volumes of waste produced by tourists combined with Mediterranean temperatures reaching 40 degrees in the months of July and August [29] [30]. All waste and recyclables are collected and managed by the island of Kefalonia council at a purpose built depot in Argostoli, the capital of the island (Figure 6) [21]. This houses eleven waste collection vehicles, eight of which are deployed on scheduled collection rounds while the other three are for additional rounds deployed in the summer months to manage the increase of waste generated by tourists. The depot has a fully equipped workshop and can carry out all minor and major repairs to the fleet. A washing bay has also been constructed outside so that all of the waste collection vehicles can be washed at the end of their days work to eradicate any germs or flies. The council also has two waste collection vehicles which work in the town and the outskirts of Lixouri. The smaller of the two collection vehicles also collects waste in Zola, Assos and the Port of Fiskardo.

There are four principal waste systems for the island: plastic bin liner (city of Argostoli's narrow back streets), 240 and 360 litre containers for the collection of dry recyclables, 660 litre roll top steel and plastic flat top containers and 1100 litre roll top steel and plastic flat top containers. The 660 and 1100 litre containers are used for the collection of both recyclable and non-recyclable waste, distinguished in colour; blue represents the collection of dry recyclables while green is for the collection of non-recyclable waste. Containers are placed at communal collection points along the street where domestic dwellings, apartments, shops and taverns can place their waste and dry mixed recyclables for collection. Hotels are mostly provided with 1100 litre roll top containers but these are stored on their own grounds. The collection service begins at 3-5 am every day to avoid traffic and disrupting tourists. On a Sunday, the waste collection service covers the whole island in the summer months and in the winter months the service is only carried out in Argostoli. Each collection crew is manned by a driver and two personnel who position the containers to the rear of the collection vehicles for emptying by the vehicle's lifting equipment.

There are two waste collection rounds which collect waste from the City of Argostoli and the tourist resort of Lassi. One concentrates on collecting the waste in the long streets while the other vehicle concentrates on collecting waste in the areas of Argostoli and Lassi with restricted access. A small satellite 7.5 tonne waste collection vehicle also collects waste in the tight access areas and provides a second collection service for the larger inner city streets mid morning with the round finishing between 2-3 pm. There are also separate collection vehicles which collect waste from Sami, Antisamos and Agia Effimia, Poros, Skala and Katelios, Lourdas, Pesada and Gerasimos, Minia, Metaxata, Lakithra, Spartia and the International Airport.

From 1996, plan was put in place to update existing fleet of waste collection vehicles. The island purchased a new Mercedes SK 202418 tonne two axle chassis with Faun Variopress waste collection bodywork and trunnion lifting equipment mounted to it. This vehicle was assigned to collect waste in the town of Sami, Antisamos

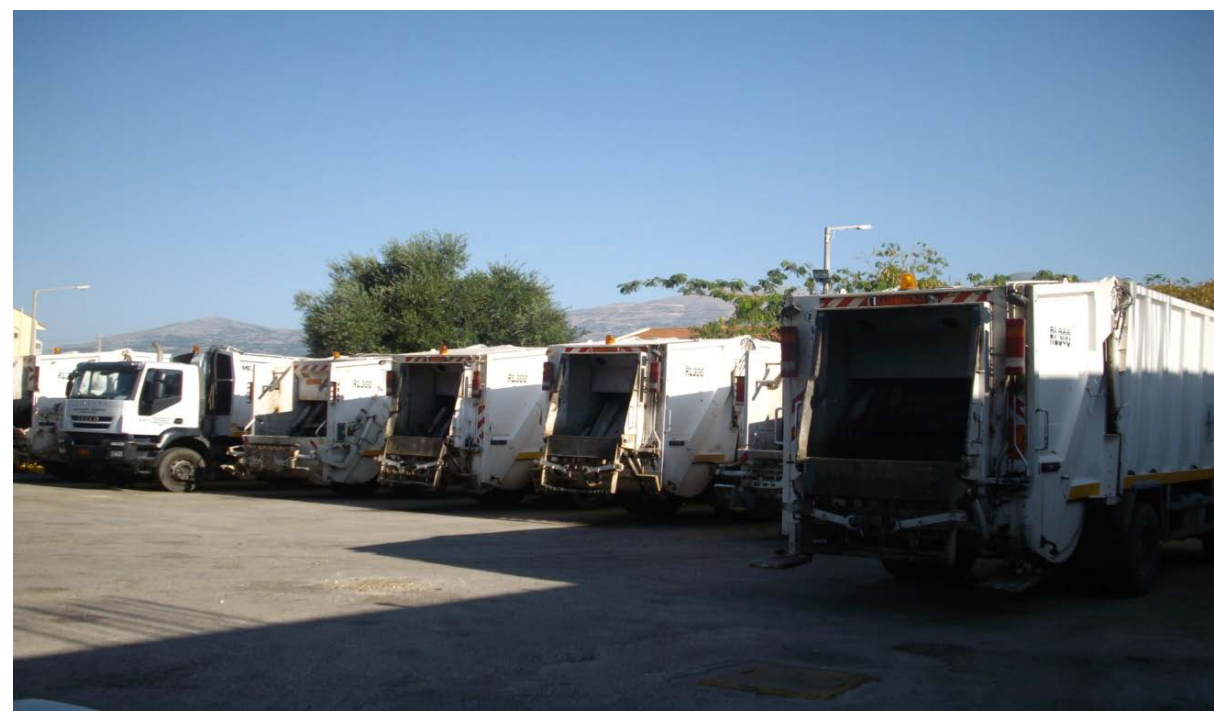

Figure 6. Fleet of waste collection vehicles used to collect municipal and commercial waste at their purpose built depot in Argostoli (authors photograph). 
and Agia Effimia. The second purchase was in 1999, a Mercedes Atego 1523 two axle chassis of 15 tonnes with 12 cubic metres Kaoussis CRV 1600 rotating drum compaction equipment. This equipment featured a trunnion and bar lift for the emptying of containers of 80 - 1100 litre capacity DIN 30,700/DIN 30,740. This vehicle was purchased for accessing the narrows streets across the island, for example, in Lixouri, Zola, Assos and the Port of Fiskardo as well as some small villages near to Argostoli.

In 2004 the island council also purchased a Mercedes Atego 8157.5 tonne two axle chassis with Mazzocchia satellite waste collection equipment mounted to it from Greek waste collection vehicle manufacturer Kaoussis. This collection vehicle also featured a bar lift which could empty containers from 80 -1100 litres capacity DIN 30,700 and DIN 30,740 types. This collection vehicle was purchased to collect waste in the narrow streets of Argostoli and once full, it would off load its waste into the Mercedes Actros 2640 three axle chassis with Kaoussis Norba RL300 22 cubic metre bodywork for onward transport to the sanitary landfill site of the island [29] [31].

In 2008, four more larger waste collection vehicles were purchased; three Iveco Eurocargo 190EL28 two axle 18 tonne chassis with Kaoussis Norba RL300 16 cubic metre bodywork and an Iveco Trakker 450 three axle 26 tonne chassis with Kaoussis Norba RL300 22 cubic metre bodywork. The purpose for buying these four new collection vehicles was to replace the last of the remaining Mercedes SK Faun/Kuka Rotopress rotating drum waste collection vehicles initially bought from Germany second hand as well as also replacing one of the Mercedes Actros 1831 two axle Kaoussis Norba RL300 16 cubic metre waste collection vehicles purchased new in 2002.

\subsection{Case Study 4: Tourism Waste Management in the Municipality of Kalithea-Rhodes}

To the south of the city of Rhodes lies the Bay of Faliraki in the district of Kalithea. This is a busy tourist resort for holidaymakers worldwide (CIWM, 2011). Built along the bay is the busy resort of Faliraki, which generates fifty tonnes of waste a day, mostly produced from the hotels, apartments, bars and taverns (Figure 7). Typical composition of waste samples is: household waste (37\%), Paper (10\%), cardboard (5\%), plastics (10\%), glass (7\%), metal (4\%), textiles (2\%) wood (0.5\%) organic fraction (24.5\%) (Table 1). The collection of this waste is carried out by the municipality of Kalithea. The municipality operate three waste collection vehicles, two of

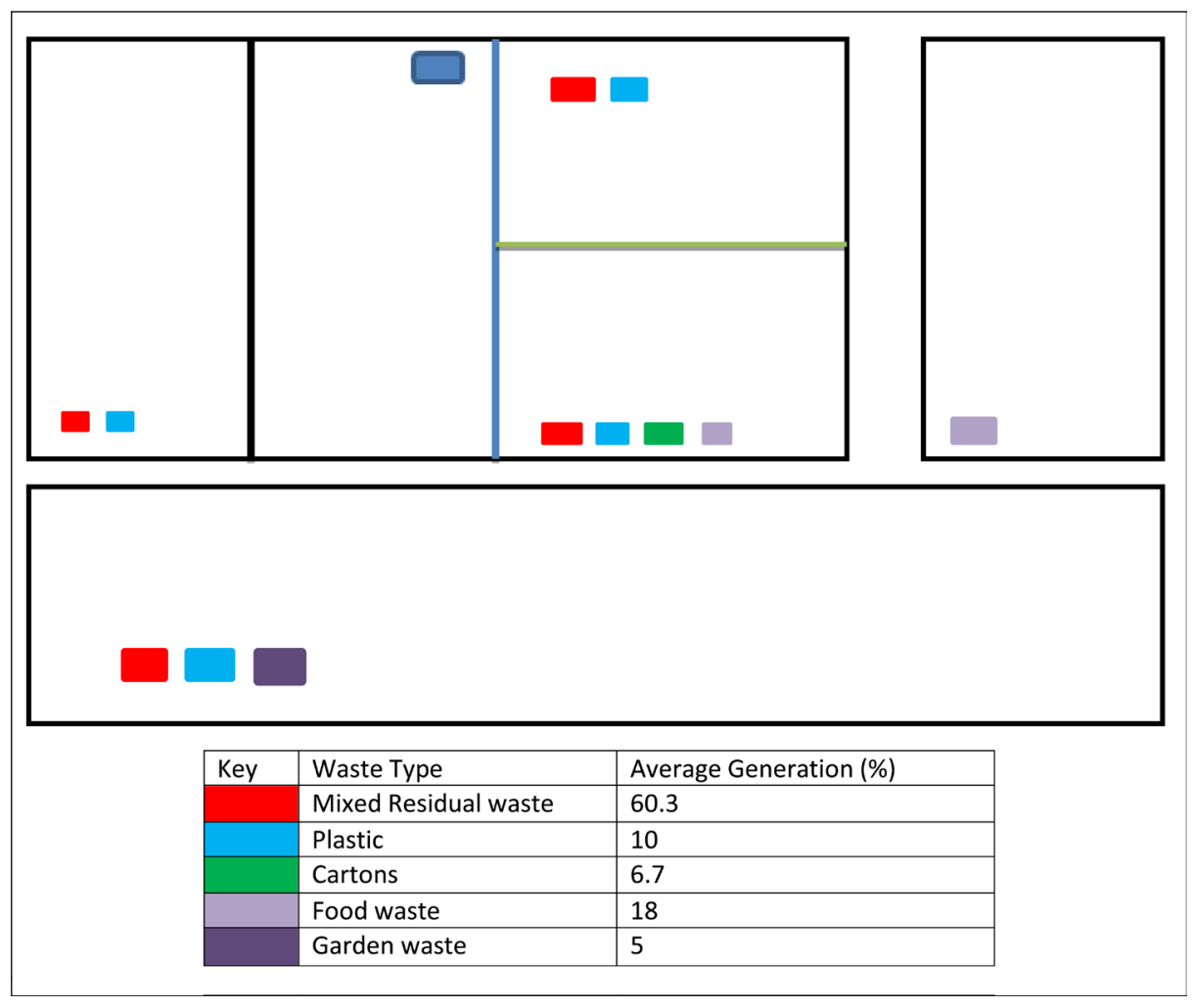

Figure 7. A waste map for a typical hotel in Kalithea-Rhodes based on Pirani, et al. [4]. 
Table 1. Types of non-hazardous waste in the hotel industry (based on Zein et al. [32].

\begin{tabular}{|c|c|c|}
\hline $\begin{array}{l}\text { Non-hazardous } \\
\text { waste type }\end{array}$ & Components & Source \\
\hline Household wastes & $\begin{array}{l}\text { Food/kitchen waste, used or dirty paper and wrapping, } \\
\text { plastic wrapping or bags, composite wrappers }\end{array}$ & Hotel’s different departments \\
\hline Cardboard & Packaging & Hotel's different departments \\
\hline Paper & $\begin{array}{l}\text { Printed documents, brochures, menus, maps, magazines, } \\
\text { newspaper }\end{array}$ & Administration, reception, guest rooms, restaurants \\
\hline Plastic & $\begin{array}{l}\text { Bags, bottles (that did not contain hazardous material), } \\
\text { household goods, individual portion wrappers for various } \\
\text { products }\end{array}$ & $\begin{array}{l}\text { Kitchen, restaurants, bars, guest rooms, } \\
\text { administration }\end{array}$ \\
\hline Metal & $\begin{array}{l}\text { Tin cans, jar lids, soda cans, food containers, mayonnaise, } \\
\text { mustard and tomato puree tubes, aluminum packaging }\end{array}$ & Kitchen, restaurants, bars, guest rooms \\
\hline Glass & Bottles, jars, flasks & Kitchen, restaurants, bars, guest rooms \\
\hline Cloth & Tablecloths, bed-linen, napkins, clothes, rags & Kitchen, restaurants, bars, bathrooms, guest rooms \\
\hline Wood & Wooden packaging, pallets & Purchasing department \\
\hline Organic waste & $\begin{array}{l}\text { Fruit and vegetable peelings, flowers and plants, } \\
\text { branches, leaves, grass }\end{array}$ & Kitchen, restaurants, bars, guest rooms, gardens \\
\hline
\end{tabular}

which service the hotels and the town of Faliraki, while the latter services the villages which lie inland.

Along the public highways are communal collection points with 120, 240, 660 and 1100 litre containers. Tourists from apartments, bars and tavernas deposit their waste into these containers to await collection. The hotels are supplied with 660 and 1100 litre containers into which they place their waste. Due to the warm temperatures, each hotel has a cold room where they can store several of their 660 litre containers. Food waste is deposited into these containers by employees at the hotels. The cold room is fitted with a sealed door and the waste is chilled by a thermostat to eradicate the possibility of the waste decaying in the warm temperatures while it awaits collection, preventing a health threat to tourists and hotel employees.

As a result of the recent economic recession, the municipality doubled shift two of its waste collection vehicles. The first shift starts at $5.00 \mathrm{am}$ and finishes at $10.00 \mathrm{am}$, servicing central Faliraki and its villages, while the second shift starts at 11.00 am finishing at $4.00 \mathrm{pm}$. The second shift services all of the hotels located along Faliraki Bay. The waste collection crews consist of a driver and two loaders. The loaders place the containers to the rear of the refuse collection vehicle for emptying, and also load any excess waste into the refuse collection vehicle that has built up from tourism. The wearing of high visibility clothing by operatives is not enforced in Greece, so none of the operatives were wearing protective clothing, except gloves.

Once the vehicle is full, the vehicle and crew travel to the sanitary landfill site in the centre of the Island. Upon arrival, the waste collection vehicles enter the weighbridge and the vehicles' gross weight and payload are accurately recorded. Once weighed, the refuse collection vehicle proceeds up the steep incline to the tip face of the landfill where the driver discharges its load. Plant machinery then covers the waste with soil, to prevent it blowing off site. The vehicle then returns to the weighbridge area and the driver collects his waste transfer note from the weighbridge operator. The landfill site has been operational since 2005, and is now nearing its end of life. At the present, neither a new landfill site has been provided nor has any alternative waste treatment infrastructure been built. The existing landfill is built to a sanitary specification and incorporates leachate treatment facilities, as well as methane being flared off site.

Near to the entrance to the site, and located near the weighbridge, is an area where waste electronic and electrical equipment is stored. This waste is collected by authorised transporters and delivered to authorised treatment facilities on the mainland, or shipped by authorised exporters for further processing. Wood waste is also stored here for reprocessing whilst wood waste which is contaminated is shredded on site and pre-treated before it is sent for disposal.

Recycling infrastructure is also increasing on the Island. Recent recycling initiatives on the Island have been driven mostly by the private sector. Perme [33], a mainland contractor which has been in existence since 1999, has rolled out a glass recycling and cardboard waste collection services to hotels, bars, tavernas and shops. This is to help Greece meet its statutory EU recycling and landfill diversion targets. Each hotel is supplied with a bottle bank which is emptied twice a week by one of Perme's collection vehicles. This vehicle consists of a tipper 
with crane to lift the bottle banks and discharge their contents into the collection vehicle. Once the collection vehicle has finished its round, it delivers its load to Perme's waste transfer station in Kalithea. The glass is collected by private hauliers and shipped to the mainland for reprocessing. A rear loading refuse collection vehicle also collects the paper and cardboard waste and delivers the collected material to the waste transfer station where it is baled, awaiting transport for reprocessing.

Following recent Greek economic recession, additional powers have devolved to Local Authorities. Although each municipality has its own waste collection vehicles, each municipality on the Island now has to seek guidance from Rhodes town before they can make any local decision. Rhodes town has decided that privatisation is the way forward for waste collection services. So far, there are two private waste collection contractors collecting municipal solid waste on behalf of municipalities-Helesi S.A. (Hellenic Environmental Systems Industry) in Ialysos and Afantou and Perme (Environmental Transport Ltd) in Archangelos and Lindos [28]. Helesi S.A. has a proven track record in collecting municipal waste on behalf of Greek municipalities and was involved in a joint venture in 2004 with Spanish waste collection contractor Urbaser S.A. in collecting all of the waste generated by the Olympic games in Athens [34].

\subsection{Strategies for Minimizing Waste in the Hospitality/Tourism Industry}

Waste minimisation, through redesigning products, changing societal patterns (education and training) and purchasing with eco-intelligence ("green" purchasing), is widely considered the most environmentally resourceful, economically efficient, and cost effective long term approach to managing waste during the life cycle of a product [35].

Very often, those involved with the tourism industry are faced with barriers to reducing waste due to a lack of information and guideline, time constraints, space and finance [36]. Furthermore, waste management practices are not uniform and so waste prevention can often require altering the way business is conducted. Nevertheless, there are a number of simple, yet effective, tools to preventing facility waste at source. These can be characterised into accommodation, food and beverage, open space, and administrative functions [37].

Accommodation

1) Introducing sorting and recycling plastic bottles, tins and glass from guest rooms;

2) Providing bulk dispensers and eliminate the use of individual bottles;

3) Returning laundered clothes to guests in reusable cloth bags/baskets thereby eliminating plastic bags;

4) Instructing housekeeping not to replace half-used rolls of toilet paper/tissue boxes and leave replacements for guests to use when required;

5) Using partially used items from guestrooms in employee restrooms or donating to charities; and

6) Extending the lifespan of equipment by having it serviced regularly.

Food and Beverage

1) Establishing purchasing guidelines to encourage the use of durable equipment and high-quality, reusable products such as linens and tableware;

2) Serving yoghurt, butter and jam in serving dishes rather than individual jars;

3) Using refillable containers for such items as sugar, salt, pepper, flour, soda, syrup and cream;

4) Replacing plastic/foam cups, utensils and plates with washable cups, dishes and utensils;

5) Delivering juices in bulk containers and made available from dispensers;

6) Using cloth rolls towels or hand dryers instead of paper products;

7) Donating unused food to local food banks or other charitable organizations; and

8) Collecting unusable food scraps and giving or selling them to local pig farmers for animal feed.

Open Spaces

1) Phasing out the use of hazardous materials where possible; and

2) Using organic gardening techniques and products.

Administrative Functions

1) Using bulletin boards for memos, pamphlets and brochures instead of circulating copies to all staff;

2) Using e-mail;

3) Where printing is required, print on both sides;

4) Reuse envelopes for internal staff documents; and

5) Purchasing refillable pens and toner cartridges. 


\section{Conclusions}

It is evident from this investigation that the environmental impacts of a linear buy-use-dispose economy seriously undermine long-term sustainability and climate change objectives. A shift towards a much more integrated approach to address the interdependent social, economic and environmental systems is required so as to address this persistent and systemic challenge. This includes decoupling, in absolute terms, the lock-ins between resource efficiency and other environmental pressures associated with such destinations, including transport, agriculture and industry. However, neither environmental policies nor economic and technology-driven efficiency gains alone are likely to be sufficient to achieve the vision; a fundamental transition in the character of institutions, practices, technologies, policies, lifestyles and perceptions are needed, underpinned by well designed, long term physical and socio-economic planning.

Waste reduction provides a number of long-term benefits to tourism facilities and their host communities such as cost savings, greater operational efficiency, environmental protection, improved image and customer satisfaction. Based on the case studies that have been described, it is clear that waste management presents a great test for island tourist destinations. Barriers constraining the efficient collection, transfer and disposal of waste include, climatic conditions, land mass and topography, financial restraints, planning issues, limited infrastructure, changing consumption patterns, dynamic population and seasonal variations in waste quantity and composition. To ensure sustainable waste management practices in these settings, dynamic, location based strategies must be adopted; no single system is ideal for all four regions studied. Planning for such systems should take a staged approach, incorporating a range of human, physical, technical, fiscal and legal instruments, with decision support tools to hand. That way, it will be possible to:

- Generate accurate waste management data;

- Model future scenarios;

- Undertake robust feasibility analysis to assess costs, optimize service delivery, capacities and efficiencies.

In the destinations examined, much of the waste produced is disposed of in communal open skips. Such mechanisms quickly become filled with recyclable material, compostable material and general waste in an uncontrolled way, thus being an inefficient economic and environmental disposal route. In areas where space is restricted, balers and compactors should be utilised to produce clean, segregated, recyclable materials which will attract a higher value, as opposed to low value unprocessed waste. In addition, it would also allow for a thorough understanding of the character and composition of waste produced from tourism related services as well as establishes the sector's overall GHG emission contribution.

\section{Recommendations}

- A detailed quantitative assessment of waste generation from each of the Islands is required to be able to more accurately predict quantities and composition of the waste streams. In this regard, adopting a time series analysis approach, rather than year-to-year, would allow for the implementation and verification of long term robust management strategies.

- A reliable and well-planned (local) monitoring programme concerning the number of tourists, their socioeconomic situation and waste generation habits is required so as to be able to predict more accurately which part of the Island's waste arising is related to tourism and which part relates to other activities.

- Explore waste management strategies that go beyond conventional recycling, to include Extended Producer Responsibility (EPR), green procurement and eco-taxes, so as to challenge producers, re-conceptualise product designs and ultimately move towards a zero waste target.

- Encourage greater public education and community engagement initiatives, i.e. public meetings, waste specific training for businesses and island clean ups assisted by local school, shops, businesses, Island residents and tourists, so as to raise awareness of waste related issues, as well as overcome the divide that commonly exists between local residents and the tourism industry.

- Adopt a more proactive approach towards the development and application of the public-private partnerships (PPP) model for waste management on touristic Islands. In this regard, collaborative approaches to governance and decision making will help to address some of the ongoing issues faced in the case studies, i.e. financial constraints, a lack of capacity and limited education, thus allowing current initiatives to be assessed and future opportunities identified. 


\section{References}

[1] Hall, D. (2010) Waste Management in Europe: Framework, Trends and Issues. Public Services International Research Unit (PSIRU). http://brecht.tttp.eu/IMG/pdf/it 10 2010-02 Waste trends-3.pdf

[2] Santamarta, J.C., Rodríguez-Martín, J., Paz Arraiza, M.P. and López, J.V. (2014) Waste Problem and Management in Insular and Isolated Systems. Case Study in the Canary Islands (Spain). IERI Procedia, 9, 162-167. http://dx.doi.org/10.1016/j.ieri.2014.09.057

[3] Willmott, L. and Graci, S.R. (2012) Solid Waste Management in Small Island Destinations: A Case Study of Gili Trawangan, Indonesia. TEOROS, Special Issue, 71-76.

[4] Denafas, G., Ruzgas, T., Martuzevicus, D., Shmarin, S., Hoffmann, M., Mykhaylenko, V., Ogorodnik, S., Romanov, M., Neguliaeva, E., Chusov, A., Turkadze, T., Bochoidze, I. and Ludwig, C. (2014) Seasonal Variation of Municipal Solid Waste Generation and Composition in Four East European Cities. Resources, Conservation and Recycling, 89, 22-30. http://dx.doi.org/10.1016/j.resconrec.2014.06.001

[5] Pirani, S.I. and Arafat, H.A. (2014) Solid Waste Management in the Hospitality Industry: A Review. Journal of Environmental Management, 146, 320-336. http://dx.doi.org/10.1016/j.jenvman.2014.07.038

[6] Mateu-Sbert, J., Ricci-Cabello, I., Villalonga-Olives, E. and Cabeza-Irigoyen, E. (2013) The Impact of Tourism on Municipal Solid Waste Generation: The Case of Menorca Island (Spain). Waste Management, 33, 2589-2593. http://dx.doi.org/10.1016/j.wasman.2013.08.007

[7] Skordilis, A. (2004) Modelling of Integrated Solid Waste Management Systems in an Island. Resources, Conservation and Recycling, 41, 243-254. http://dx.doi.org/10.1016/j.resconrec.2003.10.007

[8] Denafas, G., Ruzgas, T., Martuzevicus, D., Shmarin, S., Hoffmann, M., Mykhaylenko, V., Ogorodnik, S., Romanov, M., Neguliaeva, E., Chusov, A., Turkadze, T., Bochoidze, I. and Ludwig, C. (2014) Seasonal Variation of Municipal Solid Waste Generation and Composition in Four East European Cities. Resources, Conservation and Recycling, 89, 22-30. http://dx.doi.org/10.1016/j.resconrec.2014.06.001

[9] Kariminia, S., Ahmad, S.S. and Hashim, R. (2012) Assessment of Antarctic Tourism Waste Disposal and Management Strategies towards a Sustainable Ecosystem. Procedia-Social and Behavioural Sciences, 68, 723-734. http://dx.doi.org/10.1016/j.sbspro.2012.12.262

[10] Shamshiry, E., Nadi, B., Bin Mokhtar, M., Komoo, I., Saadiah Hashim, H. and Yahaya, N. (2011) Integrated Models for Solid Waste Management in Tourism Regions: Langkawi Island, Malaysia. Journal of Environmental and Public Health, 2011, Article ID: 709549. http://dx.doi.org/10.1155/2011/709549

[11] Von Bertrab, A., Hernandez, J.D., Macht, A. and Rodriguez, M. (2009) Public-Private Partnerships as a Means to Consolidate Integrated Solid Waste Management Initiatives in Tourism Destinations: The Case of the Mexican Caribbean. http://www.iswa.org/uploads/tx_iswaknowledgebase/3-340paper_long.pdf

[12] McDevitt, C. (2008) Sustainable Waste Management within the British Virgin Islands. http://www.globalislands.net/userfiles/bvi_2.pdf

[13] Xin, T.K. and Chan, J.K. (2014) Tour Operator Perspectives on Responsible Tourism Indicators of Kinabalu National Park, Sabah. Procedia-Social and Behavioural Sciences, 144, 25-34. http://dx.doi.org/10.1016/j.sbspro.2014.07.270

[14] De Cantis, S., Parroco, A.M., Ferrante, M. and Vaccina, F. (2014) Unobserved Tourism. Annals of Tourism Research, 50, 1-18. http://dx.doi.org/10.1016/j.annals.2014.10.002

[15] Chen, M.C., Ruijs, A. and Wesseler, J. (2005) Solid Waste Management on Small Islands: The Case of Green Island, Taiwan. Resources, Conservation and Recycling, 45, 31-47. http://dx.doi.org/10.1016/j.resconrec.2004.12.005

[16] German Federal Ministry for Economic Cooperation and Development (BMZ) (2010) Sustainable Waste Management in the Tourism Sector of the Mexican Caribbean. http://www.giz.de/en/worldwide/24475.html

[17] World Business Council for Sustainable Development (2005) ITC-Welcomegroup Hotels-A Green Model for EcoTourism. http://www.wbcsd.org/web/publications/case/itc_gsc_full_case_final_web.pdf

[18] Papachristou, E. and Chatziaggelou, H. (1991) Qualitative and Quantitative Analysis of Municipal Solid Waste of Rhodes, AUTH.

[19] Gidarakos, E., Havas, G. and Ntzamilis, P. (2005) Municipal Solid Waste Composition Determination Supporting the Integrated Solid Waste Management System in the Island of Crete. Waste Management, 26, 668-679. http://dx.doi.org/10.1016/j.wasman.2005.07.018

[20] Hitachi Zosen Inova (2011) Mallorca/Spain: Energy from Waste Plant. http://www.hz-inova.com/cms/images/stories/pictures/download/hzi_ref_mallorca_en.pdf

[21] Byrne, T. (Ed.) (2012) Waste Collection and Transfer in Touristic Locations from a Practical Perspective. D-Waste, Athens. 
http://www.d-waste.com/reports/waste-collection-and-transfer-in-touristic-locations-from-a-practical-perspective201209-05-13-36-45_-detail.html\#.UyxGb4XPvbo

[22] TIRME (2014) Overview of Processes at TIRME WTE Facility. http://www.yokogawa.com/success/newenergy/suc-TIRME.htm

[23] ONWASTE (2013) Changing the Face of Waste on Mallorca. http://www.onwaste.com/images/stories/residuos/recogida_transporte/waste_mallorca.pdf

[24] Zero Waste Europe (2012) Mallorca; Sun \& Waste! http://www.zerowasteeurope.eu/2012/11/mallorca-sun-waste-the-sunny-and-shady-sides-of-zero-waste/

[25] INTEREMPRESAS (2013) Marcos Gorrin Linares Manages the Collected of Waste in Tenerife. http://www.interempresas.net/Recycling/News/108120-Marcos-Gorrin-Linares-manages-collected-waste-in-Tenerife.h $\underline{\mathrm{tml}}$

[26] ONWASTE (2013) Tenerife's Trash, Trucks and Transfer Stations. http://www.onwaste.com/images/stories/residuos/recogida_transporte/RWW_757_Tenerife.pdf

[27] Mark Allen Group (2011) Tenerife’s Trash, Trucks and Transfer Stations. Recycling and Waste World Magazine, June, 4.

[28] ONWASTE (2013) Marcos Gorrin Linares Manages Waste Collection on the Island of Tenerife. http://www.onwaste.com/images/stories/residuos/recogida_transporte/marcos_gorrin_linares.pdf

[29] Penwell (2013) Case Study — Waste Collection on the Island of Kefalonia. http://www.waste-management-world.com/articles/2013/12/case-study-waste-collection-on-the-island-of-kefalonia.ht $\underline{\mathrm{ml}}$

[30] Faversham House Group (2014) From One Island to Another. Local Authority Waste and Recycling Magazine, February, 12-13.

[31] INTEREMPRESAS (2013) A Examen el Sistema de Recogida de Residuos en la isla de Cefalonia (Grecia). http://www.interempresas.net/Equipamiento Municipal/Articulos/115468-A-examen-el-sistema-de-recogida-de-residu os-en-la-isla-de-Cefalonia-\%28Grecia\%29.html

[32] Zein, K., Wazner, M.S. and Meylan, G. (2008) Best Environmental Practices for the Hotel Industry [WWW Document]. Sustainable Business Associates.

http://www.sbaint.ch/spec/sba/download/BGH/SBABGEHOTELLERIEENG2008.pdf

[33] Perme (Environmental Transport Ltd). Accessed on 23 March 2014. http://www.perme.gr/index.php?cPath=45\&sess=da784687d655dd065d0a573cd0041740

[34] Hellenic Environmental Systems Industry (2007) Services. http://www.helesi.com/english/services gb.html

[35] Remolador, M.A. (2011) Guide to Greening Hotels through Waste Management \& Green Purchasing. http://nerc.org/documents/green_hotels_guide.pdf

[36] United Nations Environment Programme (2003) A Manual for Water and Waste Management: What the Tourism Industry Can Do to Improve Its Performance. http://www.unep.fr/shared/publications/pdf/WEBx0015xPA-WaterWaste.pdf

[37] Radwan, H.R., Jones, E. and Minoli, D. (2010) Managing Solid Waste in Small Hotels. Journal of Sustainable Tourism, 18, 175-190. http://dx.doi.org/10.1080/09669580903373946 